\title{
Children in War: Reintegrating Child Soldiers
}

\author{
Alcinda Honwana
}

\begin{abstract}
This article discusses the issue of child soldiers by weaving together the threads of experiences of violence, terror and survival narrated by children directly involved in armed conflicts. Despite the fact that the majority of them have been forced to enter the military, they are not just empty vessels into whom violence is poured. Having started as victims, many are converted into perpetrators of the most violent and atrocious deeds. The article suggests that former child soldiers exercise a 'tactical agency' to deal with the immediate circumstances of their situation. The interstitial position of child soldiers, as both victims and perpetrators of violence, places them in a unique position vis-à-vis their communities and society in general. The article examines the role of local community strategies for healing, rehabilitation and social reintegration of former child soldiers. But beyond social healing in the immediate aftermath of war, these children and their families need to be given access to education, training and employment to rebuild their lives.
\end{abstract}

In recent decades, children and youth feature centrally as both the targets and the perpetrators of violence. In nearly every war and civil conflict, children are among the principal victims. The situation has worsened in recent years because civil wars and conflicts without clearly defined state actors have grown more prominent, and children suffer more in these 'irregular' conflicts.

The involvement of young people in warfare is not a recent phenomenon; it is deeply rooted in the history of Western as well as non-Western civilisations. In Europe during the Middle Ages, upper-class boys who hoped to become knights would serve as squires. Around the age of 13, the boy was apprenticed to a knight. He was taught skills with the sword, lance and shield and learned the duties and responsibilities of knighthood. As a squire grew older, he was expected to follow his master into battle and protect him if the knight fell in battle (see Brett and McCallin 1996). Italians called a young soldier who followed his knight into battle on foot infante, which literally means child, and collectively these children made up the infanteria, or infantry.

Young people have been at the forefront of warfare and political conflict in many parts of the world. In revolutions with strong ideological motivations, children and youth have often been fighters. Stories of wars of national independence often feature the heroic deeds of children of both sexes who were too young to join the armed forces or even the guerrillas. Today, children feature as combatants in conflict zones around the globe, in places as diverse as Angola, Afghanistan, the Balkan region, the Great Lakes region in Africa, Cambodia, Colombia, Northern Ireland, Palestine, Sierra Leone and Sri Lanka, to mention just a few. The scale of the contemporary problem is unprecedented, both in the numbers of young people involved and in the degree of their participation. Indeed, the magnitude of children's involvement in war is such that the international community has begun to take more forceful actions to protect children's rights in contexts of war.

This article focuses mainly on the experiences of children affected by armed conflict in Mozambique and Angola. It examines the situation of children who have been caught in warfare as child soldiers for many years and became perpetrators of horrific deeds. In Mozambique, RENAMO, the rebel group, is reported to have had more than 10,000 child

IDS Bulletin Volume 40 Number 1 January 2009 (c) 2009 The Author(s). Journal compilation (c) Institute of Development Studies Published by Blackwell Publishing Ltd, 9600 Garsington Road, Oxford OX4 2DQ, UK and 350 Main Street, Malden, MA 02148, USA 
soldiers in its ranks, some as young as six years old. In Angola, a 1995 survey found that 36 per cent of children had accompanied or supported soldiers and 7 per cent of children had fired at somebody (UNICEF 1996). But the conditions of those civil wars, while extreme, were more visible than they were unusual. The instrumentalisation of children as soldiers extends far beyond Mozambique and Angola. The article also examines some of the strategies for healing and social reintegration of former child soldiers through community mechanisms, and calls for greater empowerment of communities through development strategies that will create better education and promote job creation. Thus, the article links the political, social and, some would say, moral issue of child soldiering with poverty eradication and larger developmental and community-rebuilding processes.

\section{The story of Marula}

In 2000, Ivorien novelist Ahmadou Kourouma wrote his prize-wining novel, Allah n'est pas obligé, a tale of an orphan who becomes a child soldier during the wars in West Africa. The main character presents himself by saying:

My name is Birahima. I could have been a boy like any other ... A dirty boy, neither better nor worse than all the other dirty boys of the world ... With my Kalashnikov I killed lots of people. It is easy. You press and it goes tra-lala. I am not sure that I enjoyed it. I know that I suffered a lot because many of my fellow child soldiers have died.

(Kourouma 2000, author's translation)

Let me share with you the story of Marula, a former child soldier I met and interviewed in southern Mozambique. Through Marula's story, I hope to share some of the experiences and challenges faced by young people in the context of war in Africa, and highlight the complexities of their agency and their prospects for the future.

At the age of ten, Marula was kidnapped by RENAMO insurgents during an attack on his village in southern Mozambique. Marula, his father and his younger sister were forced to carry military equipment and looted goods and follow the soldiers. They walked for three days before reaching the RENAMO camp. There, the family was separated. While his father was sent to the men's sector and his sister to the women's sector,
Marula was ordered to join a group of young boys. A few weeks later, Marula started military training. He was not allowed to see his father and sister, but they managed to arrange secret meetings on a few occasions. During one of these meetings they agreed to run away together. But they were caught attempting to escape. As punishment, and for his own life to be spared, Marula was ordered to kill his father. And so he did. Following this first killing, Marula grew into a fierce RENAMO combatant and was active for more than seven years. He does not remember how many people he tortured, how many he killed, how many villages he burnt and how many food convoys and shops he looted. After the war, he returned to his village. But his paternal uncle, the only close relative who survived the war, refused to welcome him home. The uncle could not forgive Marula for killing his brother, the boy's own father.'

These events established Marula's transitions from child to soldier, civilian to combatant; from victim to perpetrator, innocent to guilty. They also shaped his identity at that point as a child soldier, a RENAMO combatant and a killer rejected by his own family.

The binary child-soldier produces an oxymoron, a hybrid that conflates victim and perpetrator. Child soldiers find themselves in an unsanctioned position between childhood and adulthood. They are still undeniably very young but no longer innocent; they acquire the skills of seasoned soldiers but are not adults yet. The possession of guns and a licence to kill removes them from childhood. They are located in a twilight zone; a transition in which the worlds of childhood and adulthood 'rub against each other in ... uneasy intimacy' (De Boeck 2000). According to Hommi Bhabha (1994) these 'in between' spaces provide the terrain for elaborating new strategies of selfhood and initiate new signs of identity.

It is difficult to regard Marula as simply a victim who was compelled to kill and, therefore, bears no responsibility for his act of patricide. Yet, his responsibility is different from that of a young man who kills his father for some imagined benefit. Civil war and peace engender quite distinct moral environments. Rather than conducting a philosophical inquiry into the degrees of guilt attributable to children and 
youths coerced into civil wars, the point here is to try and understand the new identities they develop in these interstitial positions.

It is clear from former child soldiers' accounts of their recruitment that coercion predominated. Many boys like Marula were kidnapped or forced into military camps. The context of civil war made detachment from armed conflict impossible, even if enlistment was voluntary. The initiation of young people into violence was a carefully orchestrated process of identity reconfiguration aimed at cutting their links with society.

Young boys and girls were initiated into violence through a deliberate process of terror. Terrified themselves, they were prepared to inflict terror on others. As Marula's account shows, these were not two separate phases in which boys were first brutalised by soldiers and then forced to brutalise civilians. Rather, the infliction of suffering on others was part of their own initiation into violence. It can be argued that having started out as victims many of them become perpetrators of the most violent and atrocious deeds. Yet such a linear progression does not fully represent the complex, intertwined and mutually reinforcing acts of violence of which they are both victims and perpetrators. Some were most victimised in the very act of murdering others. Marula's act of murder detached him from his immediate family; the violation of fundamental kinship ties was performed by his own hand.

In this ambiguous context, these young men and women somehow managed to develop a world of their own. They found space and time to miss their relatives, cry over their pains and sorrows; they found ways of beating the system by deceiving their commanders, planning to escape and refusing certain tasks. The accounts below highlight the complexity of their lives and identities in the military.

When I was kidnapped, I gave the soldiers a false name, not my real one. I didn't want them to know my family and make my parents suffer. ${ }^{2}$

I was very scared of going into combat. I thought I was going to die. Before going on missions, I always thought of my parents and asked in silence for them to pray for $m e{ }^{3}$
Ifelt compassion for the people and, if the commander was not there, I would let them run ... instead of killing them. It was very hard to kill. ${ }^{4}$

Social theorists agree that agency involves the exercise of power. Anthony Giddens (1984) reformulated the concept of human agency. For him, 'agency concerns events of which an individual is the perpetrator, in the sense that the individual could, at any phase in a given sequence of conduct, have acted differently. Whatever happened would not have happened if that individual had not intervened' (Giddens 1984: 9).

For Giddens, agency is intrinsically connected to power. Power presumes regularised relations of both autonomy and dependence between actors in contexts of social interaction. All forms of dependence offer some resources whereby those who are subordinated can influence the actions of their superiors. But that power can be constrained by a range of circumstances. Indeed, choice is always exercised within a specific situation defined by given constraints. Many former soldiers claim that they 'had no choice'. Yet recognition of the constraints under which they acted need not mean the dissolution of agency as such.

This view of agency makes these young soldiers agents in their own right, because they can, at certain moments, mobilise resources to alter the activities of others and, thereby, of themselves. They can pretend to be ill to avoid certain tasks; they can plan to escape; they can deliberately fail to perform their duties properly. This interplay constitutes what Giddens calls the 'dialectic of control' (Giddens 1984: 16).

In order to make sense of the agency of these young soldiers, I draw on the distinction between strategies and tactics proposed by French philosopher Michel de Certeau in his book The Practice of Everyday Life. De Certeau defines strategy as the calculation or manipulation of force-relationships, which requires a defined physical or social space. In this space the actor has autonomy to generate relations with an exterior distinct from it (de Certeau 1984: xix).

A tactic, on the other hand, is a calculated action taken by someone who lacks autonomy and who is acting in the physical or social space which is not their own. 
The place of a tactic is the space of the other ... it must play on and with a terrain imposed on it ... it operates in isolated actions, blow by blow. It takes advantage of 'opportunities' and depends on them ... this gives a tactic more mobility, to be sure, but a mobility that must accept the chance offerings of the moment. (de Certeau 1984: 37)

As de Certeau recognises, tactics are the 'art of the weak'. Subordinated subjects must constantly manipulate events in order to turn them into opportunities.

These young combatants exercised tactical agency to cope with the concrete immediate conditions of their lives in order to maximise the circumstances created by their violent military environment. They acted from a position of weakness. They had no power base, no locus from which to act independently. As de Certeau suggests, their tactical actions happened 'blow by blow' to seize the openings any given moment offered. The testimonies presented above clearly illustrate the point.

In contrast, the exercise of strategic agency would require a basis of power. It would also require mastery of the larger picture, some comprehension - however inaccurate - of the long-term consequences of their actions in the form of political gain, benefits, or profits. The majority of child soldiers' positions seem to have entirely lacked such a perspective. Many demobilised soldiers regarded their service in the military as a waste of time. Child soldiers' position as tactical agents connects well with the concept of multiple identities, which can be instrumentally used to cope with the constraints of one's situation.

\section{The challenges of healing and social reintegration}

I feel so bad about the things that I did. It disturbs me so much that I inflicted death on other people. When I go home I must do some traditional rites because I have killed. I must perform these rites and cleanse myself. I still dream about the boy from my village that I killed. I see him in my dreams, and he is talking to me, saying I killed him for nothing, and I am crying. ${ }^{5}$

In the aftermath of war, how does Marula reconcile with his family? His uncle's reluctance to accept him back into the family shows the moral and emotional dilemmas created by a war that pulled apart communities and split entire families. Postwar healing, reconciliation and reintegration are, thus, fundamental for the survival of these war-affected communities. In Mozambique, community-based healing and reconciliation mechanisms dominated the rural areas in the absence of state-led strategies. Cleansing and purification rituals were performed to deal with the emotional and social problems of war-affected populations.

These rituals were based on cultural notions of social pollution that can affect individuals or groups who come in contact with death and bloodshed: those who killed or saw people being killed, or those who simply travel to unknown territory. These individuals and groups are believed to be polluted by the spirits of the dead of the war, or by unknown wandering spirits. In local cosmologies, burial rituals are vital for the stability of the community as they help place the dead in their proper position in the world of the ancestors. The dead of the war are not properly buried; their spirits wander around and become malevolent spirits that can afflict not only the individual who committed the offences but also the entire family or community. Individuals exposed to social pollution, like the child soldiers, are believed to be potential contaminators of the social body. Therefore, the cleansing process is seen as a fundamental condition for collective protection against pollution and for the social reintegration of waraffected people into society. Let me take you through a typical cleansing ritual for a former child soldier, as described by a relative.

When the young man came back from the war his relatives took him to the ndumba [the house of the spirits] to present him to the ancestral spirits of the family. The grandfather thanked the spirits for their protection as his grandson was able to return alive. A few days later, a female healer came to perform the cleansing ritual. Followed by the family, she took the young man to the bush, and there a small hut covered with dry grass was built. Dressed with the dirty clothes he brought from the RENAMO camp, the young man entered the hut and undressed himself. Then fire was set to the hut, and an adult relative helped him out ... The hut, the clothes and everything else that he brought from the camp was burned to ashes and buried. Everybody, especially the young man, left the ritual place without looking back. At the family home the young man's body was cleansed - he 
inhaled the smoke of herbal remedies, he drunk tea from herbal medicines and he took a bath with water also treated with herbal remedies. These procedures were aimed at cleansing him inside and out. The ritual ended with the sacrifice of chicken to make the ritual meal which was shared by those present and with the ancestral spirits.

This healing ritual brings together a series of symbolic meanings aimed at cutting the young man's link with the war. While modern psychotherapeutic practices emphasise verbal exteriorisation of the affliction, here through symbolic meanings the past is locked away. This is seen in the burning of the hut and the clothes, the cleansing of the body, and not looking back at the past. To talk and recall the past is not necessarily seen as a prelude to healing or diminishing pain. Indeed, it is often believed to open the space for the malevolent forces to intervene.

These cleansing rituals resemble what anthropologists call rites of transition. The young man undergoes a symbolic change of status from someone who has existed in a realm of sanctioned norm-violation or normsuspension, to someone who must now live in a realm of peaceful behavioural and social norms, and conform to these. Until the transition is complete (through ritual performance), the subject is considered to be in a dangerous state, a marginal, 'betwixt and between', ambiguous state. For this reason, the young man cannot engage in full social interaction until the rituals have been completed (Green and Honwana 1999). The performance of these rituals and the politics that precede them transcend the particular individual and involve the collective body. The family and community members are involved, as are the ancestral spirits, in mediating for a good outcome. This case illustrates the interdependence between the living and the dead in this cultural context. The living must acknowledge the dead, both the ancestors and the dead of the war, to bring order and stability to their lives.

In this way, former child soldiers' transition from war to peace, from soldier to civilian, from perpetrator of violence into active citizenship becomes embedded in local culture with its particular meaning systems. Of course, these rituals have their limitations and may fail to address all the dimensions of young soldiers' afflictions. Also, some youths are sceptical of such practices and might refuse them as a way to break away from 'tradition'. However, in the postwar chaos when governments and international organisations are unable to provide effective mechanisms, these community rituals are often the only means available to help communities move forward. They are also critical in bringing people together in forgiveness and reconciliation.

In a study carried out in Mozambique with a group of former child soldiers, Neil Boothby (2006) points out that the vast majority of the group of former child soldiers in his study 'became productive, capable and caring adults. At the same time, none of them are truly free from their pasts, and rely solely on themselves, families and friends for comfort and support'. Boothby argues that apprenticeships, community sensitisation campaigns and the outward support of traditional community rituals were critical to the successful recovery of many of the former child soldiers. He concludes that, above all, the crucial element was the need to be accepted by their families and communities after the war. And this is precisely what these community healing rituals offered to the former child soldiers - forgiveness and re-acceptance into the community. In this way, the community also reconciled itself with its troubled past. But these rituals might have also had the function of bonding them to rural society in ways that the war and city life may have been unable to do.

However, while community healing and cleansing rituals offered forgiveness and re-acceptance into community and, thus, helped facilitate their psychological and emotional recovery, the fact that former young soldiers had no education and marketable skills and had no employment or other forms of livelihood makes them vulnerable to myriad problems. In these circumstances, programmes for healing war-affected youth must be complemented by job creation and skills training programmes. A general alleviation of poverty is urgently necessary in order to offer these young people some prospect of a better future.

In the aftermath of the war, many demobilised and 'reintegrated' youth continue to be as vulnerable as they were before joining the military. The 
socioeconomic situation in the rural areas where most of them came from worsened; war brought not only displacement but also a massive destruction of social and economic infrastructure, including housing, health clinics, and schools. Following peace, extreme poverty and difficult environmental conditions continue to prevail. Young former soldiers and captive girls return to villages and communities physically devastated by the war and with profound social wounds. Some are easily absorbed back into violence, whether urban criminal gangs, illicit business dealings, or rebel militias in new conflicts. Thus, the rehabilitation and social reintegration of children affected by armed conflict should go hand in hand with larger strategies of social development and poverty eradication.

\section{Conclusion}

This article argues that the issue of child soldiers must be addressed by weaving together the threads of experiences of violence, terror and survival narrated by these children and their families. Despite the fact that the majority of them have been forced to enter the military, they

\section{Notes}

1 Marula was 20 years old when I met him and conducted this interview in September 1995, in Chibuto Gaza province, Mozambique. Marula mentioned that in the beginning he was very afraid of the war but he had no alternative but to adjust to it in order to live. With time he learned to live that life.

2 Gito, interviewed in March 1998 in Moxico by the Christian Children's Fund (CGF) team in Angola.

\section{References}

Bhabha, H. (1994) The Location of Culture, London: Routledge

Boothby, N. (2006) 'What Happens When Child Soldiers Grow Up? The Mozambique Case Study', Intervention 4.3: 244-59

Brett, R. and McCallin, M. (1996) Children: The Invisible Soldiers, Växjö, Sweden: Rädda Barnen, Swedish Save the Children de Certeau, M. (1984) The Practice of Everyday Life, trans. S. Rendall, Berkeley: University of California Press

De Boeck, F. (2000) 'Borderland Breccia: The Mutant Hero in the Historical Imagination of a Central-African Diamond Frontier', Journal of Colonialism and Colonial History 1.2: 1-44 are not empty vessels into whom violence is poured. Having started as victims, many of them are converted into perpetrators of the most violent and atrocious deeds. In this transformation process, they also exercise agency of their own - a 'tactical agency'. The interstitial position of child soldiers, as both victims and perpetrators of violence, places them in a very unique situation vis$\grave{a}$-vis their communities and society in general.

The article suggests that community processes of healing, rehabilitation and social reintegration of youth affected by armed conflict can be important local mechanisms for helping these youths. However, such mechanisms should go hand in hand with much larger strategies of social development and poverty eradication. Beyond healing the social and emotional wounds in the immediate aftermath of war, lasting results will only be achieved if the world is committed to addressing the structural causes of this problem by seriously undertaking poverty reduction and economic development and facilitating political participation and social stability.

3 Marcos, a 20-year-old former soldier from Mozambique who fought alongside RENAMO troops, interviewed by the author in Chibuto in September 1995.

4 Zita, a former boy soldier in RENAMO, Mozambique, interviewed by the author in September 1995 in Macia.

5 A 16-year-old girl after demobilisation from an armed group. Coalition to Stop the Use of Child Soldiers (US State Department, TIP Report 2005).

Giddens, A. (1984) The Constitution of Society: Outline of the Theory of Structuration, Berkeley: University of California

Green, E. and Honwana, A. (1999) 'Indigenous Healing of War-Affected Children in Africa', IK Notes 10, July, Washington DC: World Bank

Kourouma, A. (2000) Allah n'est pas obligé, Paris: Editions du Seuil

UNICEF (1996) The State of the World's Children 1996: Children in War, New York: UNICEF

US State Department (2005) Trafficking in Persons Report 2005, Washington DC: US State Department 